Scientia Marina 71(1)

March 2007, 129-135, Barcelona (Spain)

ISSN: 0214-8358

\title{
Sediment as a constituent of Mediterranean benthic communities dominated by Caulerpa racemosa var. cylindracea
}

\author{
LUIGI PIAZZI ${ }^{1}$, DAVID BALATA ${ }^{1}$, LUCA FORESI $^{2}$, CRISTINA CRISTAUDO ${ }^{1}$ \\ and FRANCESCO CINELLI ${ }^{1}$ \\ ${ }^{1}$ Dipartimento di Biologia, Università di Pisa, via A. Volta 6, I-56126 Pisa, Italy. E-mail: lpiazzi@ discat.unipi.it \\ ${ }^{2}$ Dipartimento di Scienze della Terra, Università di Siena, via Laterina 8, I-53100 Siena, Italy.
}

\begin{abstract}
SUMMARY: Mediterranean macroalgal assemblages in areas invaded and non-invaded by Caulerpa racemosa var. cylindracea were compared and trapped sediments were characterised. Results showed that assemblages invaded by $C$. racemosa var. cylindracea differed greatly from non-invaded ones: encrusting and erect algae, both articulated and foliose, decreased in invaded areas, while opportunistic filamentous species increased their abundance The percentage of sediment was 7 times higher in areas invaded by $C$. racemosa var. cylindracea than in non-invaded areas. Characteristics of trapped sediments were similar in all the studied assemblages, while redox values were lower in the invaded ones. Results suggested that sediment constitutes an important component in C. racemosa var. cylindracea populations, probably enhancing the competitive ability of this species.
\end{abstract}

Keywords: biological invasions, Caulerpa racemosa, macroalgal assemblages, Mediterranean Sea, sediments.

RESUMEN: EL SEDIMENTO COMO CONSTITUYENTE DE COMUNIDADES BENTÓNICAS MEDITERRÁNEAS DOMINADAS POR CAULERPA RACEMOSA VAR. CYLINDRACEA. - Las comunidades de macroalgas mediterráneas en áreas invadidas por C. racemosa var. cylindracea y áreas no invadidas fueron comparadas y el sedimento retenido caracterizado. Los resultados muestran que las áreas invadidas por C. racemosa var. cylindracea difieren de forma marcada de las poblaciones no invadidas: algas incrustantes y erectas, articuladas y foliosas, decrecen en las áreas invadidas, mientras que las especies filamentosas oportunistas aumentan su abundancia. El porcentaje de sedimento fue siete veces mayor en áreas invadidas por $C$. racemosa var. cylindracea que en áreas no invadidas. Las características del sedimento atrapado fueron similares en todas las poblaciones estudiadas, mientras que los valores del potencial redox fueron menores en las zonas invadidas. Nuestros resultados sugieren que el sedimento constituye un componente importante en las poblaciones de $C$. racemosa, var. cylindracea, posiblemente aumentando la capacidad competitiva de esta especie.

Palabras clave: invasiones biológicas, Caulerpa racemosa, comunidades macroalgales, Mediterráneo, sedimentos.

\section{INTRODUCTION}

Physical and biological factors interact to determine the temporal and spatial distribution of benthic marine assemblages, making it difficult to understand mechanisms of community regulation (Schiel and Forster, 1986; Paine, 1990; Lüning, 1993; Middelboe et al., 1997; Baynes, 1999). In fact, the effects of physical factors can strongly modify the results of interspecific interactions, such as competition or predation (Underwood and Jernakoff, 1984; Andrew and Viejo, 1998; Kaehler and Williams, 1998; Benedetti-Cecchi et al., 2000). In coastal areas, sedimentation may be considered one of the most important physical factors affecting benthic communities (Airoldi, 2003). 
Sediments can influence benthic assemblages through several mechanisms. The disturbance caused by burial and smothering can damage a great number of benthic taxa, favouring the spread of tolerant and opportunistic species (Irving and Connell, 2002a, b; Eriksson and Johansson, 2003; Balata et $a l ., 2005)$. On the other hand, the ability of some species to trap sediments can enhance their spread, avoiding predation and favouring their competitiveness (Airoldi, 2003). The latter mechanism has been widely studied in relation to turf-forming algae (Kendrick, 1991; Airoldi et al., 1996) and it has been observed to increase the invasiveness of introduced filamentous species such as the Rhodophyta Womersleyella setacea (Hollenberg) R.E. Norris (Airoldi and Cinelli, 1997). However, the importance of sediment trapping in ecological regulation of other benthic assemblages is less known, although this mechanism has been suggested to play a key role in the competitiveness of invasive algal species (Verlaque and Fritayre, 1994).

Caulerpa racemosa (Forsskål) C. Agardh var. cylindracea (Sonder) Verlaque, Huisman et Boudouresque (Verlaque et al., 2003) (hereafter Caulerpa racemosa) represents a serious threat for native benthic communities in the Mediterranean Sea, affecting biodiversity and habitat complexity (Piazzi et al., 2005a). The interaction between $C$. racemosa and sediments has recently been investigated, showing that the alga is tolerant to high sedimentation rates and suggesting that its competitiveness could be enhanced by the ability to trap sediments (Piazzi et al., 2005b). However, limited information is available on the role of sediments in Mediterranean populations of C. racemosa.

The aim of the present study is to advance knowledge on interactions between sediments and C. racemosa. In particular, we tested the hypothesis that there were differences between invaded and non-invaded areas in i) the composition of species and morphological forms of Mediterranean shallow rocky assemblages, ii) the amount and quality of sediment trapped by the assemblages and iii) the ratio between the amount of sediment and biomass.

\section{MATERIAL AND METHODS}

The study was carried out in the northwestern Mediterranean Sea, along the coasts of Tuscany $\left(43^{\circ} 30^{\prime} \mathrm{N}, 10^{\circ} 20^{\prime} \mathrm{E}\right)$. It was conducted at $3 \mathrm{~m}$ depth on rocky bottoms invaded by Caulerpa racemosa since 1996 (Piazzi et al., 1997). The alga showed a patchy distribution, with well developed mats in invaded patches.

In the study area, 2 sites invaded by $C$. racemosa and 2 non-invaded sites interspersed among them were randomly chosen. The sites were $4 \mathrm{~m}^{2}$ wide and at least 20 metres apart. In November 2004, at the end of vegetative growth of the alga (Ruitton et al., 2005), 3 replicated samples were collected at each site. Samples comprised macroalgae and trapped sediment, and were collected by scraping $400 \mathrm{~cm}^{2}$ of substrate with hammer and chisel. Before scraping, the sediment trapped and deposited over the assemblages within each sampling surface was collected by using a suction pump to avoid the loss of the finest fractions during sampling (Balata et al., 2005).

Macroalgae were identified under the microscope. Cover of each species was estimated as vertical projection of the alga and expressed as the percentage of the sampling surface (Boudouresque, 1971). Macroalgal species were lumped into morphological groups according to Steneck and Dethier (1994) (foliose, filamentous, corticated terete, crustose, articulated) and the percentage cover of each group was calculated as the sum of the percentage cover of all the algae belonging to the group. Biomass of $C$. racemosa and macroalgae was evaluated as dry weight after $48 \mathrm{~h}$ at $60^{\circ} \mathrm{C}$.

Multivariate (PERMANOVA) and univariate (ANOVA) procedures were used to test for differences between invaded and non-invaded sites.

PERMANOVA based on permutations was used to test the hypothesis that benthic assemblages invaded by $C$. racemosa differed in composition and relative abundance from the non-invaded ones (Anderson, 2001a, b). Bray-Curtis dissimilarities for this analysis were calculated on untransformed data. The permutable units and the Mean Square (MS) used as the denominator for each source of variability are reported in Table 1 . The analysis consisted of a 2-way model with Invasion (invaded vs. noninvaded assemblages) as the fixed factor and Site (2 levels) as the random factor nested in Invasion. The amount of sediment was used as a covariable in the analysis to test possible relationships with the assemblage.

The IndVal (Indicator Value) program was used to identify the species or morphological groups that contributed most to the differences between invaded and non-invaded sites. This method was preferred to 
TABLE 1. - Results of PERMANOVA on the species composition and abundance of assemblages. Significant effects are indicated in bold. $P(\mathrm{MC}): P$ values obtained through Monte Carlo methods

\begin{tabular}{|c|c|c|c|c|c|c|c|}
\hline Source & df & MS & Pseudo- $F$ & $P$ & $P(\mathrm{MC})$ & Denominator & $\mathrm{N}^{\circ}$ perm. units \\
\hline Sediment (Covariable) & 1 & 14381.30 & 23.93 & 0.003 & & & \\
\hline Invasion $=(\mathrm{In})$ & 1 & 4953.13 & 10.28 & 0.955 & 0.007 & $\operatorname{Si}(\operatorname{In})$ & 4 \\
\hline Site $(\operatorname{In})=\mathrm{Si}(\operatorname{In})$ & 2 & 481.70 & 0.80 & 0.675 & 0.641 & Res & 12 \\
\hline Residual $=$ Res & 8 & 600.96 & & & & & \\
\hline Total & 11 & & & & & & \\
\hline
\end{tabular}

others because it combines the relative abundances of species with their relative frequencies in the groups of samples (Dufrene and Legendre, 1997). The indicator species are defined as the most characteristic species of each group, found mostly in a single group and present in the majority of the samples belonging to that group.

Data of algal biomass, species number and percentage cover of morphological groups were analysed using analysis of variance (ANOVA). Factors and levels in these analyses were the same as in the multivariate analysis. Cochran's $C$-test was utilised before each analysis to check for homogeneity of variance and data were transformed when necessary. In cases of unresolvable heterogeneous variances, analyses were run on untransformed data (Underwood, 1997).

Sediment was separated from algae and redox potential was measured at $1 \mathrm{~cm}$ depth using an Ehelectrode (Orion $250 \mathrm{~A}$ ) connected to an $\mathrm{mV}$ meter within one hour after sampling. The amount of sediment was evaluated as dry weight obtained after filtration, elimination of organic matter in $\mathrm{H}_{2} \mathrm{O}_{2}$ for 72 $\mathrm{h}$ and drying for $48 \mathrm{~h}$ at $60^{\circ} \mathrm{C}$ (Airoldi et al., 1996). Sediment weight was analysed by analysis of vari- ance (ANOVA) using the same factors and levels described above. Optical microscope analysis was performed on all the samples. X-ray powder diffractions were carried out on all the sediments to identify the mineralogical composition.

\section{RESULTS}

PERMANOVA showed significant differences between non-invaded and invaded assemblages, which were consistent between sites (Table 1). The IndVal analysis showed that algal species characterising the invaded sites were Cladophora prolifera, Hypnea musciformis, Ceramium circinatum, Spyridia filamentosa and Plocamium cartilagineum, while several erect (Halimeda tuna, Padina pavonica, Laurencia obtusa, Dictyopteris polypodioides) and encrusting coralline algae were abundant at noninvaded sites and absent at invaded sites (Table 2).

The biomass of macroalgae other than Caulerpa racemosa was $453.7 \pm 39.5 \mathrm{~g} \mathrm{~m}^{-2}($ mean $\pm \mathrm{SE}, \mathrm{n}=6)$ at non-invaded sites and $227.5 \pm 5.7 \mathrm{~g} \mathrm{~m}^{-2}$ at sites invaded by $C$. racemosa (Fig. 1a). The biomass of $C$. racemosa at invaded sites was $105.0 \pm 5.6 \mathrm{~g} \mathrm{~m}^{-2}$. The

TABLE 2. - Results of the Indicator Species Analysis (IndVal). Numbers indicate cases (numbers of samples out of 6) in which each taxon is significantly different in abundance $(\mathrm{A})$ or presence $(\mathrm{P})$ between invaded and non-invaded areas. Caulerpa racemosa was not considered in the analysis.

\begin{tabular}{|c|c|c|c|c|}
\hline \multirow[b]{2}{*}{ Taxa } & \multicolumn{2}{|c|}{ Non-invaded areas } & \multicolumn{2}{|c|}{ Invaded areas } \\
\hline & A & $\mathrm{P}$ & A & $\mathrm{P}$ \\
\hline Encrusting Corallinaceae & 56.75 & 6 & 0 & 0 \\
\hline Flabellia petiolata (Turra) Nizamuddin & 30.75 & 6 & 1.00 & 3 \\
\hline Padina pavonica (Linnaeus) Thivy & 27.25 & 6 & 0 & 0 \\
\hline Halimeda tuna (J. Ellis et Solander) J.V. Lamouroux & 17.25 & 5 & 0 & 0 \\
\hline Laurencia obtusa (Hudson) J.V. Lamouroux & 15.00 & 6 & 0 & 0 \\
\hline Dictyopteris polypodioides (A.P. De Candolle) J.V. Lamouroux & 13.00 & 6 & 0 & 0 \\
\hline Peyssonnelia rubra (Greville) J. Agardh & 3.25 & 5 & 0 & 1 \\
\hline Pseudochlorodesmis furcellata (Zanardini) Børgesen & 2.25 & 6 & 0 & 0 \\
\hline Jania rubens (Linnaeus) J.V. Lamouroux & 1.75 & 6 & 0 & 0 \\
\hline Cladophora prolifera (Roth) Kützing & 2.00 & 4 & 77.5 & 6 \\
\hline Hypnea musciformis (Wulfen) Lamouroux & 0 & 0 & 3.75 & 6 \\
\hline Ceramium circinatum (Kützing) J. Agardh & 0 & 1 & 1.25 & 6 \\
\hline Spyridia filamentosa (Wulfen) Harvey & 0 & 3 & 1.00 & 6 \\
\hline Plocamium cartilagineum (Linnaeus) P.S. Dixon & 0 & 3 & 0.25 & 6 \\
\hline
\end{tabular}



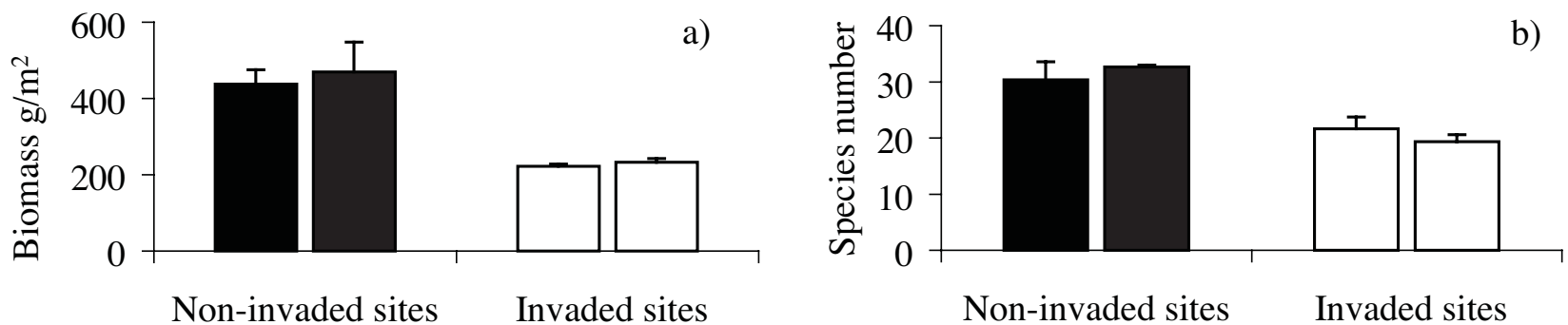

FIG. 1. - Biomass of macroalgae other than Caulerpa racemosa and species number of macroalgal assemblages at two non-invaded and two invaded sites (means $\pm \mathrm{SE}, \mathrm{n}=3$ ).

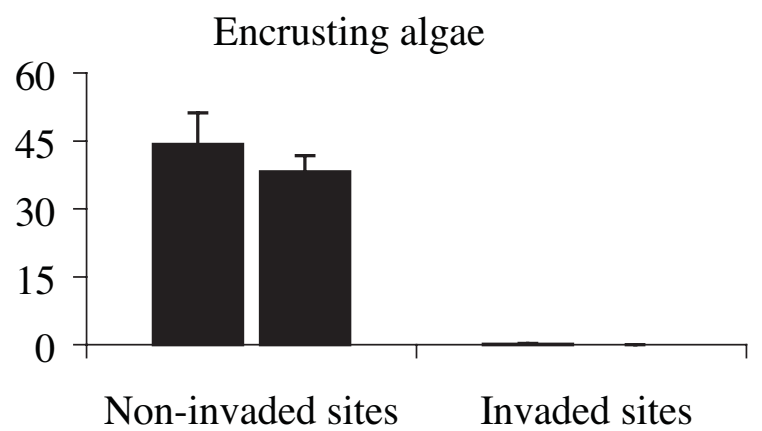

Filamentous algae

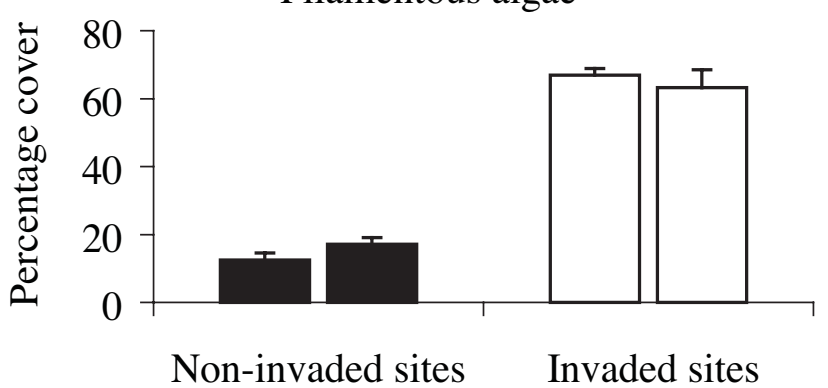

Foliose algae

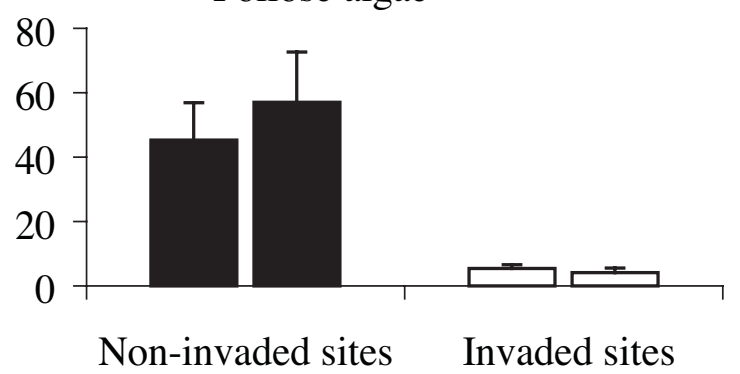

Corticated terete algae

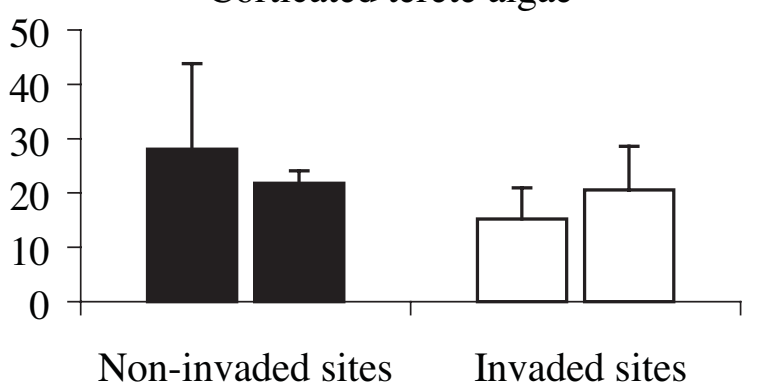

Articulated algae

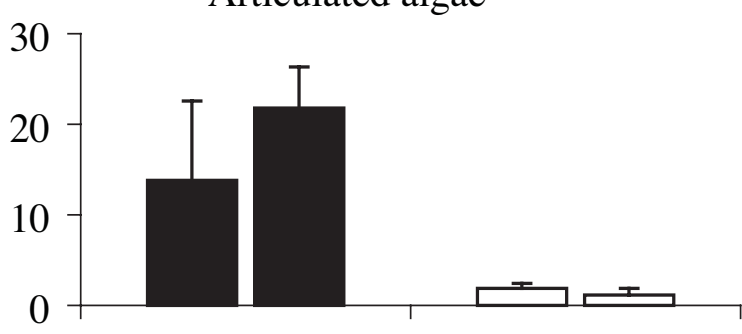

Non-invaded sites Invaded sites

FIG. 2. - Percentage cover of algal morphological groups at two non-invaded and two invaded sites $($ means \pm SE, $n=3$ ).

number of species was $31.5 \pm 1.5$ at non-invaded sites and $20.5 \pm 1.2$ at invaded sites (Fig. 1b). ANOVA detected values significantly higher at non-invaded than at invaded sites for both algal biomass and species number (Table 3). Encrusting, foliose, corticated terete and articulated algae had significantly higher percentage covers at non-invaded than at invaded sites, while filamentous species were significantly more abundant at invaded than at noninvaded sites (Table 3, Fig. 2). No significant differences were detected in the percent cover of corticated terete species (Table 3). Differences between 
TABLE 3. - Results of ANOVA analysis on total biomass, species number and percentage cover of morphological groups. Significant effects are indicated in bold.

\begin{tabular}{|c|c|c|c|c|c|c|c|c|c|}
\hline \multirow[b]{2}{*}{ Source } & \multirow[b]{2}{*}{$\mathrm{df}$} & \multicolumn{2}{|c|}{ Biomass } & \multicolumn{2}{|c|}{ Species number } & \multicolumn{2}{|c|}{ Encrusting algae } & \multicolumn{2}{|c|}{ Filamentous algae } \\
\hline & & MS & $F$ & $\mathrm{MS}^{\mathrm{I}}$ & $F$ & MS & $\stackrel{\circ}{F}$ & MS & $F$ \\
\hline Invasion $=(\mathrm{In})$ & 1 & 1.35 & 402.80 & 363.01 & 44.45 & 40.33 & 1912.36 & 7566.81 & 282.89 \\
\hline Site $(\operatorname{In})=\operatorname{Si}(\operatorname{In})$ & 2 & 0.01 & 0.12 & 8.17 & 0.69 & 0.02 & 0.58 & 26.75 & 0.93 \\
\hline Residual = Res & 8 & 0.03 & & 11.83 & & 0.04 & & 28.71 & \\
\hline Total & 11 & \multirow{3}{*}{\multicolumn{2}{|c|}{$\begin{array}{c}0.7321 \text { n.s. } \\
\ln (x+1)\end{array}$}} & \multirow{3}{*}{\multicolumn{2}{|c|}{0.7060 n.s. }} & \multirow{3}{*}{\multicolumn{2}{|c|}{$\begin{array}{c}0.5679 \text { n.s. } \\
\ln (x+1)\end{array}$}} & \multirow{3}{*}{\multicolumn{2}{|c|}{0.7060 n.s. }} \\
\hline Test $C$ Cochran & & & & & & & & & \\
\hline Trasformation & & & & & & & & & \\
\hline & & \multicolumn{2}{|c|}{ Foliose algae } & \multicolumn{2}{|c|}{ Corticated terete algae } & \multicolumn{2}{|c|}{ Articulated algae } & \multicolumn{2}{|c|}{ Sediment } \\
\hline Source & $\mathrm{df}$ & MS & $F$ & MS & $F$ & MS & $F$ & MS & $F$ \\
\hline Invasion = (In) & 1 & 6463.52 & 62.40 & 148.40 & 2.92 & 7.48 & 64.30 & 40238.18 & 56.90 \\
\hline Site $(\operatorname{In})=\operatorname{Si}(\operatorname{In})$ & 2 & 103.58 & 0.38 & 50.85 & 0.20 & 0.12 & 0.25 & 707.13 & 0.46 \\
\hline Residual = Res & 8 & 275.44 & & 253.83 & & 0.47 & & 1534.67 & \\
\hline Total & 11 & & & & & & & & \\
\hline Test $C$ Cochran & & 0.637 & & 0.707 & & 0.571 & n.s. & 0.715 & \\
\hline Trasformation & & - & & - & & $\ln (x+1$ & & - & \\
\hline
\end{tabular}

sites were not significant for all variables analysed.

The amount of sediment trapped by algal assemblages was significantly higher at invaded $\left(2962.5 \pm 533.4 \mathrm{~g} \mathrm{~m}^{-2}\right.$, mean $\left.\pm \mathrm{SE}, \mathrm{n}=6\right)$ than at noninvaded sites $\left(67.1 \pm 19.8 \mathrm{~g} \mathrm{~m}^{-2}\right)$ (Fig. 3, Table 3). The ratio between sediment and the total weight of samples (biomass + trapped sediment) showed different values in non-invaded and invaded assemblages: in non-invaded assemblages, the percentage of sediment was very low $(13.04 \pm 1.74 \%)$, while the total weight of invaded assemblages was mostly due to sediment $(88.65 \pm 1.62 \%)$.

Redox potential in the sediment trapped was 189.3 in invaded assemblages and -8.0 in non-invaded assemblages. Sediments were characterised by an

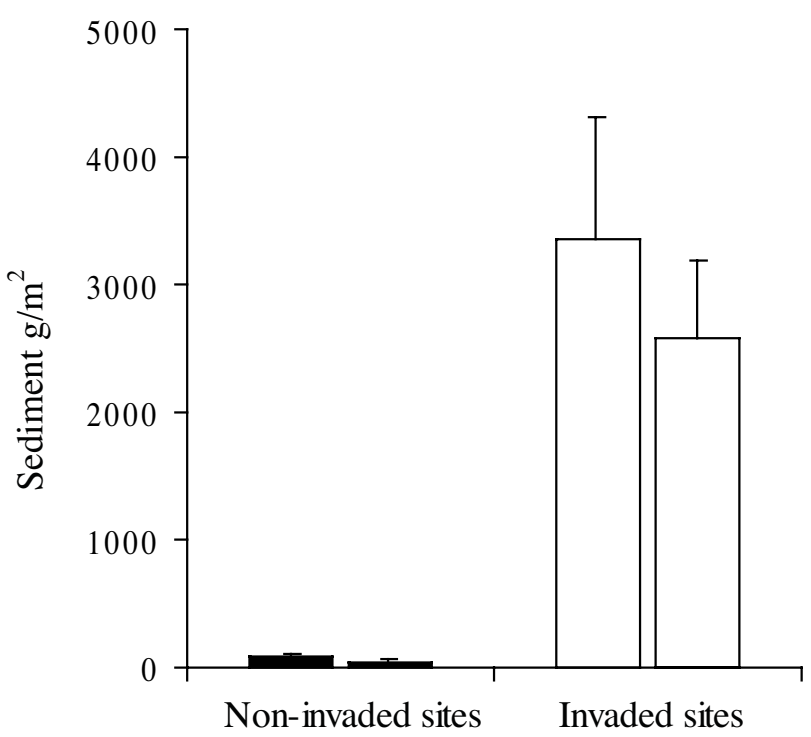

FIG. 3. - The amount of sediment trapped by macroalgal assemblages at two non-invaded and two invaded sites (means $\pm S E, n=3$ ). abundant organic carbonate fraction composed mainly of foraminifera, ostracods and fragments of molluscs and echinoids. Inorganic fraction was mainly represented by a mineralogically homogeneous fine-medium sand and scarce well rounded coarse grains. In both the assemblages, sediments were mostly composed of sand $(70.63 \%$ and $81.59 \%$ in non-invaded and invaded assemblages, respectively) and subordinate silt (29.37\% and $18.41 \%)$. The sediments showed a similar composition, mainly represented by calcite (prevalently of organic origin) and quartz and subordinate albite, orthoclase and clay minerals. The $\mathrm{CaCO}_{3}$ percentages were 32.48 and $36.76 \%$ in non-invaded and invaded assemblages respectively.

\section{DISCUSSION}

Assemblages invaded by Caulerpa racemosa differed greatly from those that were not invaded. Significant differences were also found in the amount of sediment trapped by the two assemblages.

Differences between invaded and non-invaded assemblages were in agreement with results of previous studies (Piazzi et al., 2001; Balata et al., 2004): encrusting and erect algae, both articulated and foliose, decreased in invaded areas, while opportunistic filamentous species increased their abundance. This result is emphasised by previous studies carried out in the same area before the invasion, which did not show significant differences in the structure of macroalgal assemblages at the same 
spatial scales (Piazzi et al., 2001). Macroalgae could be damaged by the overgrowth of the invasive alga, as stolons may stop or extremely reduce the availability of light irradiance. Moreover, species reproducing sexually could be damaged by the lack of substrate available for spore settlement because of pre-emption of substrate by $C$. racemosa .

Both these competition mechanisms could be enhanced by the presence of sediment trapped by stolon mats. The percentage of sediment was 7 times higher at sites invaded by $C$. racemosa than at noninvaded sites. This result suggests the ability of $C$. racemosa to trap and compact sediment. Despite the differences in the amount, characteristics of trapped sediments were similar between invaded and noninvaded sites, suggesting non-selective trapping of sediments by $C$. racemosa mats. The only difference between the two sediments concerned redox values, indicating that below the mats of $C$. racemosa a reduced environment occurs. This finding suggests that effects of $C$. racemosa and sediment can have greater implications on the system. In fact, beside influencing invaded macroalgae, the relevant decrease of redox potential of sediment could also lead to a drastic reduction in diversity of infaunal assemblages (Rosenberg and Nilsson, 2005; Burone et al., 2006).

Sediment constitutes a relevant component in assemblages dominated by $C$. racemosa, suggesting that it could be considered as a structural constituent of Caulerpa populations and of algal turfs (Kendrick, 1991; Airoldi and Virgilio, 1998). Trapped sediment could play a role in the competitive mechanisms of $C$. racemosa, based on overgrowth and pre-emption of substrate, in the same way described for mats constituted by introduced turf-forming species (Airoldi, 1998, 2003; Piazzi and Cinelli, 2001).

Results of the present and previous studies allow a synergism between $C$. racemosa and turf-forming algae to be hypothesised. C. racemosa colonisation enhances the competitiveness of filamentous species in relation to other algae. Both $C$. racemosa and turfs trap sediments, negatively affecting other algal forms. The seasonal variations in the growth of Mediterranean populations of $C$. racemosa (Ruitton et al., 2005), with peaks of abundance over short periods (Piazzi et al., 2001), could allow the recovery of native algae. However, the modifications in the structure of invaded assemblages lead to a dominance of algal turfs, which continue to accumulate sediments, making the effects of the invasion more persistent (Piazzi and Ceccherelli, 2006).

Results of this work show that sediment constitutes an important component of C. racemosa populations and suggest possible interactions between $C$. racemosa, sedimentation and turfs. Manipulative studies are necessary to verify the model suggested by this descriptive paper and to understand the mechanisms involved.

\section{ACKNOWLEDGMENTS}

We wish to thank R. Micheli for his kind collaboration in the analyses of sediments and M. Incera Filgueira for the Spanish translation.

\section{REFERENCES}

Airoldi, L. - 1998. Roles of disturbance, sediment stress and substratum retention on spatial dominance in algal turf. Ecology, 79: $2759-2770$

Airoldi, L. - 2003. The effects of sedimentation on rocky coastal assemblages. Oceanog. Mar. Biol. Ann. Rev., 41: 161-203.

Airoldi, L. and F. Cinelli. - 1997. Effect of sedimentation on subtidal macroalgal assemblages: an experimental study from a Mediterranean rocky shore. J. Exp. Mar. Biol. Ecol., 215: 271-290.

Airoldi, L. and M. Virgilio. - 1998. Response of turf-forming algae to spatial variations in the deposition of sediments. Mar. Ecol. Prog. Ser., 165: 271-282

Airoldi, L., M. Fabiano and F. Cinelli. - 1996. Sediment deposition and movement over a turf assemblage in a shallow rocky coastal area of the Ligurian Sea. Mar. Ecol. Prog. Ser., 133: 241-251.

Anderson, M.J. - 2001a. A new method for a non-parametric multivariate analysis of variance. Aust. Ecol., 26: 32-46.

Anderson, M.J. - 2001b. Permutation tests for univariate or multivariate analysis of variance and regression. Can.J. Fish. Aquat. Sci., 58: 629-636.

Andrew, N.L. and R.M. Viejo. - 1998. Effects of wave exposure and intraspecific density on the growth and survivorship of Sargassum muticum (Sargassaceae: Phaeophyta). Eur. J. Phycol., 33: 251-258.

Balata, D., L. Piazzi and F. Cinelli. - 2004. A comparison among macroalgal assemblages in areas invaded by Caulerpa taxifolia and C. racemosa on subtidal Mediterranean reefs. P.S.Z.N. Mar. Ecol., 25: 1-13.

Balata, D., L. Piazzi, E. Cecchi and F. Cinelli. - 2005. Variability of Mediterranean coralligenous assemblages subject to local variation in sediment deposits. Mar. Env. Res., 60: 403-421.

Baynes, T.W. - 1999. Factors structuring a subtidal encrusting community in the southern Gulf of California. Bull. Mar. Sci., 64: $419-450$.

Benedetti-Cecchi, L., F. Bulleri and F. Cinelli. - 2000. The interplay of physical and biological factors in maintaining midshore and low-shore assemblages on rocky coasts in the northwest Mediterranean. Oecologia, 12: 406-417.

Boudouresque, C.F. - 1971. Méthodes d'étude qualitative et quantitative du benthos (en particulier du phytobenthos). Tethys, 3: 79-104.

Burone, L., N. Venturini, P. Sprechman, P. Valente and P. Muniz.2006. Foraminifera responses to polluted sediments in the Montevideo coastal zone, Uruguay. Mar. Pollut. Bull., 52: 61-73.

Dufrene, M. and P. Legendre. - 1997. Species assemblages and indicator species: the need for a flexible asymmetrical 
approach. Ecol. Monogr., 67: 345-366.

Eriksson, B.K. and G. Johansson. - 2003. Sedimentation reduces recruitment success of Fucus vesciculosus (Phaeophyceae) in the Baltic Sea. Eur. J. Phycol., 38: 217-222.

Irving, A.D. and S.D. Connell. - 2002a. Sedimentation and light penetration interact to maintain heterogeneity of subtidal habitats: algal versus invertebrate dominated assemblages. Mar. Ecol.Prog. Ser., 245: 83-91.

Irving, A.D. and S.D. Connell. - 2002b. Interactive effects of sedimentation and microtopography on the abundance of subtidal turf-forming algae. Phycologia, 41: 517-522.

Kaehler S. and G.A. Williams. - 1998. Early development of algal assemblages under different regimes of physical and biotic factors on a seasonal tropical rocky shore. Mar. Ecol. Prog. Ser., 172: $61-71$

Kendrick, G.A. - 1991. Recruitment of coralline crust and filamentous turf algae in the Galapagos archipelago: effect of simulated scour, erosion and accretion. J. Exp. Mar. Biol. Ecol., 147: 47-63.

Lüning, K. - 1990. Seaweeds. Their Environment, Biogeography and Ecophysiology. John Wiley and Sons Inc, New York.

Middelboe, A.L., K. Sand-Jensen and K. Brodersen. - 1997. Patterns of macroalgal distribution in the Kattegat-Baltic region. Phycologia, 36: 208-219.

Paine, R.T. - 1990. Benthic macroalgal competition: complications and consequences. J. Phycol., 26: 12-17.

Piazzi, L. and F. Cinelli. - 2001. The distribution and dominance of two introduced turf-forming macroalgae in the coast of Tuscany (Italy, northwestern Mediterranean) in relation to different habitats and sedimentation. Bot. Mar., 44: 509-520.

Piazzi, L. and G. Ceccherelli. - 2006. Persistence of biological invasion effects: recovery of macroalgal assemblages after removal of Caulerpa racemosa var. cylindracea. Estuar. Coast. Shelf Sci., 68: 455-461.

Piazzi, L., E. Balestri, M. Magri and F. Cinelli. - 1997. Expansion de l'algue tropicale Caulerpa racemosa (Forsskål) J. Agardh (Bryopsidophyceae, Chlorophyta) le long de la côte Toscane (Italie). Cryptog. Algol., 18: 343-350.

Piazzi, L., G. Ceccherelli and F. Cinelli. - 2001. Threat to macroalgal diversity: effects of the introduced green alga Caulerpa racemosa in the Mediterranean. Mar. Ecol. Prog. Ser., 210: 161-165.

Piazzi, L., A. Meinesz, M. Verlaque, B. Akçali, B. Antolić, M. Argyrou, D. Balata, E. Ballesteros, S. Calvo, F. Cinelli, S.
Cirik, A. Cossu, R. D'Archino, S.A. Djellouli, F. Javel, E. Lanfranco, C. Mifsud, D. Pala, P. Panayotidis, A. Peirano, G. Pergent, A. Petrocelli, S. Ruitton, A. Žuljević and G. Ceccherelli. - 2005a. Invasion of Caulerpa racemosa var. cylindracea (Caulerpales, Chlorophyta) in the Mediterranean Sea: an assessment of the early stages of spread. Cryptog. Algol., 26: 189-202.

Piazzi, L., D. Balata, G. Ceccherelli and F. Cinelli. - 2005b. Interactive effect of sedimentation and Caulerpa racemosa var. cylindracea invasion on macroalgal assemblages in the Mediterranean Sea. Estuar. Coast. Shelf Sci., 64: 467-474.

Rosenberg, R. and H.C. Nilsson. - 2005. Deterioration of soft-bottom benthos along the Swedish Skagerrat coast. J. Sea Res., 54: 231-242.

Ruitton, S., M. Verlaque and C.F. Boudouresque. - 2005 seasonal changes of the introduced Caulerpa racemosa var. cylindracea (Caulerpales, Chlorophyta) at the northwest limit of its Mediterranean range. Aquat. Bot., 82: 55-70.

Schiel, D.R. and M.S. Foster. - 1986. The structure of subtidal algal stands in temperate waters. Oceanogr. Mar. Biol. Ann. Rev., 24: 265-307.

Steneck, R.L. and M.N. Dethier. - 1994. A morphological group approach to the structure of algal-dominated communities. Oikos, 69: 476-498.

Underwood, A.J. - 1997. Experiments in ecology. Their logical design and interpretation using analysis of variance. Cambridge University Press, Cambridge.

Underwood, A.J. and P. Jernakoff. - 1984. The effects of tidal height, wave exposure, seasonality and rock pools on grazing and the distribution of intertidal macroalgae in New South Wales. J. Exp. Mar. Biol. Ecol., 75: 71-96.

Verlaque, M. and P. Fritayre. - 1994. Modifications des communautés algales méditerranéennes en présence de l'algue envahissante Caulerpa taxifolia (Vahl) C. Agardh. Oceanol. Acta, 17: 659-672.

Verlaque, M., C. Durand, J.M. Huisman, C.F. Boudouresque and Y. le Parco. - 2003. On the identity and origin of the Mediterranean invasive Caulerpa racemosa (Caulerpales, Chlorophyta). Eur. J. Phycol., 38: 325-329.

Scient. ed.: E. Ballesteros.

Received May 23, 2006. Accepted November 15, 2006.

Published online February 26, 2007. 
